\title{
КИТАЙСЬКА НЯНЬХУА СУЧЖОУ ХVIII-XIX СТ.: ХУДОЖНЬО-СТИЛЬОВІ ОСОБЛИВОСТІ ТВОРІВ
}

\begin{abstract}
Стаття присвячена історії виникнення й розвитку особливого виду китайської народної ксилографічної няньхуа, що побутувала в Сучжоу (Китай) у XVIII столітті. Це був період активних контактів західного світу з китайською культурою, щуо зумовило своєрідність сучжсосських няньхуа другої половини XVIII-XIX століть, які мали велике значення у формуванні ранніх пейзажних картин укійо-е і мегане-е в японській ксилографії укійо-е ХVIII століття.

Методологія і методика дослідження вибудовуються на розумінні няньхуа зі Сучжоу як особливого виду пейзажних няньхуа, щзо з'явилися в Китаї під впливом західноєвропейських ідей і технік та істотно вплинули на принципи побудови простору в японській пейзажній гравюрі укійо-е.

Основними методами дослідження є: метод культурно-історичного і морфологічного аналізу, метод образно-стилістичного аналізу, щзо дає змогу об 'єктивно порівнювати специфічні художні явища, такі як застосування західноєвропейських методів у китайських і японських ксилографіях; метод композииійно-художнього аналізу, метод історичного аналізу, для порівняння, вивчення історичної документації, літературних свідчень щзодо контактів Китаю та Японії в ХVIII - ХІХ століттях.

Об'єкт дослідження: мистецттво няньхуа зі Сучжоу XVII-XIX століть, а також «перспективні картини» укой-е і мегане-е - «картини крізь окуляри». Предмет дослідження: образна система і художньо-виразні засоби няньхуа зі Сучжоу та їхній вплив на ранні пейзажні японські гравюриукійо-е і мегане-е і XVII-XVIII століть.

Наукова новизна дослідження полягає в тому, щьо вперше: виявлено і досліджено тендениї розвитку ксилографічних няньхуа зі Сучжоу, в яких використовувалися європейські методи зображення простору; виявлено основні види й жанри няньхуа зі Сучжоу, визначено специчфіку ичього явища, щчо ріниться від доброзичливих новорічних картин няньхуа; визначено основні форми впливу сучжоуської гравюри на процес формування нового бачення простору в ранній японській пейзажній гравюрі укійо-е.
\end{abstract}

Ключові слова: мистечтво Китаю, народна картина, новорічні картини, няньхуа, Сучжоу.

Zhao ZHEHGGUAN, orcid.org/0000-0002-4018-7397

Postgraduate Student at the Department of History and Theory of Arts Lviv National Academy of Arts (Lviv, Ukraine) light.monet@qq.com

\section{CHINESE NIANHUA SUZHOU OF THE XVIII-XIX CENTURIES: ARTISTIC AND STYLE FEATURES OF WORKS}

An article devoted to the study of the history of the origin and development of a special kind of Chinese folk woodcut Nianhua from Suzhou (China) in the XVIII century. This was a period of active contacts of the Western world with Chinese culture, which led to the uniqueness of Suzhou nanhua of the second half of XVIII-XIX centuries, which was important in the formation of early landscape paintings of ukiyo-e and megane-e in Japanese woodcuts ukiyo-e XVIII century.

The methodology and methods of the researching are based on the understanding of Nianhua from Suzhou as a special type of landscape nianhua, which appeared in China under the influence of Western European ideas and techniques and then increased greater influence on the principles of built space in Japanese landscape Ukiyo-e.

The main methodological studies are: the method of cultural, historical and morphological analysis, the method of image-stylistic analysis, which allow you to objectively compare special artistic manifestations, such as the use of Western European methods in Chinese and Japanese woodcuts; method of compositional and artistic analysis, method of historical analysis, which allows comparison, study of historical documentation, literary evidence of contacts between China and Japan in the XVII-XIX centuries.

Object of research: the art of nianhua from Suzhou of the XVII-X1X centuries, as well as "perspective paintings" of uki-e and megane-e - "paintings through glasses". Subject of research: the figurative system and artistic means of expression of the Nianhua from Suzhou and its influence on the early landscapes of Japanese megane-e and ukiyo-e players of the XVII-XVIII centuries. 
Scientific news of the article that for the first time: trends in the development of woodcut Nyanhua from Suzhou, which use European imaging techniques, have been identified and studied; the main types and genres of nianhua from Suzhou were identified, the special specificity of this phenomenon was determined, which is reflected in the friendly New Year's paintings of nianhua; identified the main forms of influence of Suzhou players on the process of forming a new vision of space in the early Japanese landscape graphics of Ukiyo-e.

Key words: Chinese art, folk painting, New Year paintings, nianhua, Suzhou.

Постановка проблеми. Китайська народна ксилографічна няньхуа, що побутувала в Сучжоу у XVIII столітті, як мистецьке явище має чимало «білих плям», які чекають на своїх дослідників. Зокрема, це стосується механізмів поширення західних художніх ідей і методів у 50-60-х роках XVIII століття в Китаї і проникнення їх у «закриту» Японію. Особливий інтерес становить проблема адаптації художниками Сучжоу певних європейських зразків до китайських топографічних пейзажів. Зазначимо, що в Китаї збереглося вкрай мало пейзажних картин зі Сучжоу, переважно вони знаходяться в Японії. 3 огляду на це, ми спробуємо виявити загальні риси та відмінності в процесах асиміляції китайськими та японськими майстрами західних художніх ідей і технік у середині XVIII століття.

Особливо пильну увагу упродовж багатьох десятиліть приділяли саме «старому китайському лубку», тобто новорічній картинці.Тематична своєрідність китайської народної картини може бути зведена до декількох основних однотипних груп, що виявляють іконографічну і стилістичну споріденість.

Найчисленніша група, що з'явилася на ранньому етапі розвитку няньхуа, як правило, зображувала легендарних героїв, духів-охоронців, релігійних даосько-буддійських і світських персонажів. Проте слід зазначити, що були й такі няньхуа, які повністю виходили за рамки традиційних сюжетів і груп, про які відомо вкрай мало, це пейзажні ксилографічні няньхуа зі Сучжоу. Нi у китайському, ні в українськомукому мистецтвознавстві немає жодної окремої розвідки, присвяченої сучжоуським пейзажним няньхуа.

Ймовірно, вважалося,щоусіцірозрізненіформи масового, іноді недостатньо професійного мистецтва не мають стійких традицій і загальної основи; вони не утворюють самостійного виду мистецтва, яким $є$ у Китаї новорічна картинка - няньхуа.

Отже, виявлення естетичних, художніх аспектів сучжоуської гравюри XVIII і початку XIX століття дає змогу окреслити основні тенденції розвитку не лише мистецтва Китаю, й визначити взаємозв 'язок і взаємовплив мистецтва няньхуа сучжоуського стилю і ранньої пейзажної гравюри укійо-е.
Аналіз досліджень. У Китаї наукова розробка мистецтва няньхуа почалася після утворення КНР у 1949 році. Цій темі присвячені праці відомих учених А Ин (А Ин,1954), Ван Шуцунь (Ван Шуцунь, 1959, 1988), Го Вэйцю (Го Вейцю, 1962), Чжоу Ибай (Чжоу Ибай, 1960). Поза межами Китаю дослідження мистецтва няньхуа було започатковано у Росії. Академік В. Алексєєв першим робить спробу наукового осмислення цієї своєрідної ланки народного мистецтва, що володіє столітніми традиціями (В. Алексєєв, 1966). Згодом дослідження на матеріалах колекції В. Алексєєва продовжила М. Рудова (М. Рудова, 2003). Величезний внесок у вивчення художньої спадщини няньхуа зробив Б. Ріфтін, який досліджував походження окремих колекцій та історію їхнього створення (Б. Ріфтін, 1991). Вивченням китайської народної картини займалася I. Муріан (I. Муріан, 1960). Вона опублікувала працю про китайський лубок, де розглянуто й проаналізовано основні етапи історії розвитку й формування няньхуа як самостійного виду образотворчого мистецтва. До розробкуцієї теми також долучилася Н. Червова (Н. Червова, 1960).

Під час дослідження ми спиралися на такі джерела: ксилографічні няньхуа, що містяться в музейних збірках Санкт-Петербурга, унікальна колекція академіка В. Алексєєва, що зберігається в Державному Ермітажі (Росія) (понад 2000 зразків); наукові каталоги музеїв, каталоги виставок у Китаї та Японії; няньхуа зі Сучжоу; наукові каталоги експозицій і виставок творів японської гравюри; матеріали довідково-енциклопедичного характеру японською, російською та китайською, які допомагають атрибутувати деякі сюжети няньхуа, а також теоретичний матеріал 3 мистецтва Японії і Китаю.

Мета статті полягає у виявленні впливу ксилографічних пейзажних картин зі Сучжоу на художньо-стилістичні особливості пейзажу в гравюрі укійо-е XVIII-XIX століть.

Завдання нашого дослідження: визначити основні етапи розвитку традиційної няньхуа; дослідити особливості художньо-виразних засобів і образної системи няньхуа «сучжоуського стилю» в контексті історико-культурної ситуації в Китаї в XVII-XVIII століттях; виявити специ- 
фічні відмінності сучжоуських няньхуа від традиційної народної картинки няньхуа.

Виклад основного матеріалу. Про майстерні няньхуа Сучжоу (провінції Цзянсу) уперше згадується на початку XVII століття (кінець династії Мін). За побіжного порівняння сюжетів, образів, композиційних і стилістичних прийомів традиційної китайської народної картини няньхуа і сучжоуської ксилографічної картини виразно проступає їхня несхожість, світоглядна відокремленість поглядів та уявлень. Річ у тім, що у сучжоуських ксилографічних пейзажах майстри використовували прийоми, прийняті в європейській гравюрі на міді. Крім того, були успішно освоєні прийоми лінійної перспективи і світлотіньового моделювання, раніше невідомі в Китаї. Серед сучжоуських картин були й такі, які призначалися для перегляду через проекційний ліхтар (янпянь). Можна помітити, що великі панорами зі сільськими та міськими краєвидами, що зображують на багатьох ранніх сучжоуських няньхуа, повторювали фрагменти живописних горизонтальних сувоїв XVII-XVIII століть, але виконувалися в техніці ксилографії і тільки імітували штрихову гравюру.

Спробуємо послідовно розкрити художні особливості ксилографічних няньхуа як особливого виду китайського традиційного мистецтва.

Няньхуа - це картини - побажання всього найкращого на прийдешній рік. У Китаї народні картинки малювали, вирізували на дошках, друкували і розфарбовували протягом усього року, однак продавали їх саме напередодні новорічного свята найяскравішого 3 усіх традиційних свят Китаю. Святкування починалося 23 числа 12 місяця за місячним календарем і тривало майже два тижні. Щороку на свята кожна родина вивішувала в будинку картинки доброзичливого змісту, сподіваючись, що новий рік принесе кожному щастя, здоров'я та благополуччя. Розфарбовані ксилографії (кольорові та витончені) знаходились у будинку аж до наступних свят. А напередодні Нового року їх спалювали. Вважалося, що дух домашнього вогнища донесе на небеса інформацію про те, які добрі справи зробила родина за всі 12 місяців. Замість старої вивішували нову картинку.

Сьогодні більшість няньхуа збереглася завдяки європейцям, які свого часу високо оцінили їх i зібрали перші колекції. Музей Ханенків має унікальні зразки китайської новорічної картини кінця ХІХ століття з Янлюцін.

Новорічні лубкові картини 3 тяньцзиньського повіту Янлюцін - оригінальний жанр народного мистецтва, що виник в епоху династії Мін за часів правління імператора Чунчженя (1628-1644 рр.). Розквіт цього виду народного живопису припав на роки правління імператорів Юнчжена (1723-1735 рр.), Цяньлуна (1736-1795 рр.) та Гуансюя (1875-1908 рр.) династії Цін (1644-1911рр.). У ті роки кількість зображень на таких картинах перевищила декілька тисяч.

Зображення на новорічних картинах доволі різноманітні - діти, красиві жінки, квіти і птахи, персонажі опер і різних легенд тощо. До речі, в Янлюціні й дотепер існують майстерні з виготовлення новорічних картинок. Доброзичлива символіка домінує. Художні алегорії, є основною особливістю китайських няньхуа. Ідея доброзичливості сприяла поширенню символіки взагалі, збільшенню іiі значення в житті, мистецтві та культурі країни. Протягом багатьох століть склалася практика використання ритуальних символів в іконографії, яка й вплинула на формування низки традицій. Символи проникли буквально в усі сфери життя, побуту, культури китайців. Ритуальна символіка справила величезний вплив і на розвиток китайського традиційного живопису, нею наповнені твори найвідоміших майстрів. Вплинула вона й на розвиток іконографічного лубка. Особливу групу складають новорічні картинки, пов'язані з культовою та обрядовою сторонами святкування Нового року, - це картини на релігійні сюжети. У них простежується культ поклоніння Небу, Землі, предкам, а також проявляються окремі риси релігійного даосизму, буддизму і конфуціанства. У няньхуа можна зустріти зображення буддійських, даоських $\mathrm{i}$ конфуціанських божеств. Крім того, трапляються історичні персонажі, які були особливо шанованими завдяки своєму особливому становищу, наприклад, Лао-цзи, Конфуцій, Гуань-гун, Бао-гун та ін. У системі уявлень китайців Небо керує життям і смертю, Земля породжує все суще, а в людині укладена душа всього сущого. Людина живе, спираючись на закони Неба і Землі.

Залежно від змісту няньхуа поділяються на самостійні жанрово-тематичні групи, кожна 3 яких має власну своєрідну стилістику. Одну групу представляють картини, що ілюструють сюжети літературних творів, легенд, міфів. Сюди входять і театральні няньхуа. Інша група об'єднує картини 3 релігійними та символікодоброзичливими сюжетами. Третя група - няньхуа побутового змісту, повчального характеру. Четверта група - пейзажні та декоративні картини. Осмислення подібного поділу необхідне для з'ясування місця сучжоуської пейзажної гравюри серед жанрово-тематичних груп няньхуа. 
Чітку наукову класифікацію добре відомої китайської народної новорічної картини няньхуа сформулювати складно, оскільки причиною є жанрове різноманіття творів цього виду мистецтва. Науковцям важливо з'ясувати, що об'єднує в одне ціле парні зображення Богів - охоронців домівок, доброзичливі картинки, усі символи, які породила китайська релігійна традиція, ікони для жертвопринесень, ілюстрації до театральних постановок і літературних творів, побутові замальовки, зображення красунь і фривольні картинки, гороскопи, календарі, гострі політичні замальовки на злободенну тему.Лише деяка частина цієї продукції пов'язана зі святкуванням Нового року, як, і те, що порівняно недавно цей асортимент отримав назву народної картини. Науковці в пошуках чинників таких об'єднавчих тенденцій.

Звернімося до техніки виконання няньхуа. 3'ясуємо художні, стилістичні й технічні аспекти, які відповідно до способів виробництва можна розділити на два види - живописні та ксилографії. Спробуємо виявити порівняно маловивчені точки дотику народного мистецтва та живопису Старого Китаю, визначити внутрішній генетичний зв'язок няньхуа 3 деякими напрямами живопису періоду Сун (X-XIII ст.).

Няньхуа - односторінкова ксилографія масового попиту, аналог російського лубка. Усі, що існували до того часу монохромні гравюри на дереві на окремих листах, вважаються попередниками няньхуа.

Відомо, що витоки няньхуа сягають релігійної гравюри, але, водночас, щоб повніше усвідомити природу китайського лубка, необхідно щоразу враховувати глибинний зв'язок зі живописом. На певному рівні постійно відбувався процес взаємодії яскравого народного няньхуа з естетичним мистецтвом вищих верств суспільства. У цьому проявляється певна закономірність, оскільки і народна картина, і традиційний китайський живопис становили собою два потоки, які не могли не мати точок дотику. Китайська культура і традиційний живопис справили величезний вплив, передусім на власне народне мистецтво.

Розглянемо витоки появи нового типу живопису, приблизно на стику періодів П'яти династій (907-960) та епохи Північної Сун (960-1127). Цей час можна вважати часом зародження ксилографічного няньхуа, що поступово стає важливою частиною народного мистецтва. Розпис вручну не міг більше задовольняти потреби суспільства. Найтісніше пов'язана з цим жанром саме ксилографія. Коли виникла ця оригінальна художня форма, традиційний живопис вже існував на етапі свого найвищого розвитку, був поширений і мав певний вплив. Наприкінці X століття склалося кілька напрямів у живописі, які по-різному розуміли завдання зображення навколишнього світу. Ці напрями співіснували один з одним і мали неабиякий вплив на народну культуру.

Живопис «веньженьхуа», що дослівно означає «живопис літераторів», мав великий вплив на няньхуа. Художники «веньженьхуа», або художники-вчені, як їх ще називали, значною мірою визначили подальший напрям китайського живопису другої половини XI століття. Будучи противниками академічних прийомів живопису, вони проповідували вільну творчість, що грунтується не на тренуванні й практиці, а на вмінні вловити внутрішню сутність предмета. Створені в цей період няньхуа, безумовно, підпали під вплив живопису «веньженьхуа» i, можливо, безпосередньо запозичували іiі виразні засоби і методи.

За зразками, зробленими за допомогою гравіювання на дерев'яних дошках епохи Тан (618-907) і Сун (960-1279) можна побачити, що ксилографія того часу вже набула поширення, і велика кількість професійних художників займалися iï створенням. Завдяки співпраці професійних художників і граверів 3 народу майстри безпосередньо стали застосовувати форми традиційного живопису для створення народних картин. До моменту виникнення сунських майстерень, які займалися виготовленням няньхуа, способи гравіювання по дереву поєдналися $з$ традиціями живопису, що призвело до популярності ксилографічних няньхуа в народі.

Самобутнім є напрям живопису, який представляли художники Кайфинскої академії, що отримала при імператорі Хой Цзун (1100-1125) більшу самостійність. Отож, академічний живопис Сун, зображення квітів і птахів, безумовно, вплинули на розвиток няньхуа, яка перебрала багато художньо-стилістичних рис живопису, але по-своєму їх інтерпретувала. Відбувався процес взаємовпливу. Так, у творчості художників-інтелектуалів поступово з'являлися теми, які відображали місцеві обряди і звичаї, ілюстрували легенди і розповіді про духів. Тематика картин обмежувалася тепер зображенням квітів, птахів та історичних персонажів. Живопис наповнився особливостями й традиціями китайського народу, що збагатило їх зміст.

Найяскравішим прикладом процесу взаємовпливу живопису i картин няньхуа, $\epsilon$ творчість представника живопису інтелектуалів епохи Мін (1368-1644) Чень Хуншоу (1598-1652). (Цзинь Чжилинь, 2004: 111-125). Багато картин з його творчої спадщини збереглося до наших днів. Навіть за побіжного порівняння сюжетів, образів, компози- 
ційних і стилістичних прийомів простежуємо світоглядну єдність поглядів та уявлень. Монохромні гравюри на дереві на окремих аркушах вважаються попередниками няньхуа. 3 винаходом ксилографії виготовлення односторінкових відбитків випередило друкування книг з чисто економічних міркувань. Ремісники вирізували і друкували продукцію, якій був гарантований швидкий збут: амулети, календар із пророцтвами. У місті Дуньхуані (провінція Гансу) знайдені два друкарські календарі за 822 і 877 роки, картини для данини (було прийнято дарувати монастирю мальовані картинидля зберігання з нагоди прийняття обітниці, але з'ясувалося, що відбитки дешевші й доступні більшій кількості прихожан). Торгівля такого роду друкарською продукцією була зосереджена навколо буддійських монастирів. У прагненні розширити перелік попередників няньхуа до них належать i деякі малюнки, наприклад два унікальні сунські малюнки нашовку, які зберігаються в Гугуне. Вони детально досліджені й описані Чжоу Ибаєм (Чжоу Ибай, 1960: 376-383) і є зразками перших справжніх ілюстрацій до театрального спектаклю.

У всі альбоми народної картини незмінно поміщають три репродукції зі збірки Державного Ермітажу, датовані XII століттям і знайдені в Хара Хото. Одна 3 них із твору під умовною назвою «Чиновник зі слугою» (Державний Ермітаж (Санкт-Петербург), X 2531), виконаного тушшю, виготовленого як імітація ксилографічної гравюри, що може бути ескізом для гравюри. Дві інші чудові зразки гравюри на дереві: «Прекрасний вигляд красунь різних династій» (Державний Ермітаж (Санкт-Петербург), Х2530) i «Вірний боргу, хоробрий Уаньский князь Гуань» (Державний Ермітаж (Санкт-Петербург), X 2519). Усі три аркуші виготовлені на той час за межами Китаю, в місті Піньяні (нині Ліньфень на території сучасної провінції Шаньсі), яке було центром книгодрукування в чжурчженській державі Цзінь. Ми можемо лише припускати, наскільки рівень розвитку цзінської односторінкової гравюри відповідає тому, яким було життя на той час у Китаї. Джерела згадують про те, що на міських ринках активно торгували паперовими картинками чжсиха (живопис пальщем).

Якщо говорити про Цзінь, то можна вважати показовим одночасне існування односторінкових гравюр і малюнків, що їх наслідують. Це, так само як і найвища якість різьблення, навряд чи свідчить про великі наклади цих творів.

У цзінських гравюрах вже присутне тематичне розмаїття, характерне для пізніших графічних робіт. На думку К. Флуг, «Чотири красуні» могли бути ілюстрацією до театральної п’єси, оскільки Піньян за династії Юань був нарівні з Пекіном (тоді Даду) центром друкування театральних п’єс (К. Флуг, 1959: 100]. Офіційний характер напису на гравюрі із зображенням Гуань Юя наводить на думку, що цей твір міг призначатися для храму бога Гуаня. Юанських одно сторінкових гравюр збереглося вкрай мало. Одну з них «Коштовності, поширювані наусі чотири боки», Ван Шуцунь показує в альбомі няньхуа (Ван Шуцунь, 1959).

Мінських односторінкових гравюр до наших днів дійшло дещо більше, наприклад, календар на 1488 рік «Дев'ять дев'яток» («Цзю цзю ту»). Першим зразком «справжньої» няньхуа прийнято вважати гравюру 1597 року. «Шоу-син ту» із зображенням бога довголіття Шоу-сина, близнюків Хэ-Хэ в оточенні восьми даоських безсмертних. Гравюра «Шоу-син ту» виконана в техніці кольорового друку з кількох дощок без застосування підфарбовування від руки, зображення поміщене в широку орнаментальну рамку. На думку Ван Шуцуня, картина $є$ не стільки іконою, скільки народною театральною картиною яньхуа ілюстрацією, до юанської драми «Вісім безсмертних бажають довголіття Хазяйці Заходу», тобто Сі Ван Му (Ван Шуцунь, 1959: 24). Цей зразок перший $з$ тих, що збереглися, виконаний в техніці багатоколірного друку.

Відтепер і назавжди яскравість і барвистість $€$ неодмінним атрибутом няньхуа. Няньхуа майже завжди виконана в техніці ксилографії. Дослідники старовинних народних картин зазвичай недооцінюють твори, виконані в іншій техніці, наприклад, олеографію початку XX століття. Барвистість у «нових» няньхуа є домінуючою. Колір прийшов у ксилографічну гравюру 3 книг. Техніка багатоколірного друку була відома давно, але застосовувалася лише для тканин, ще починаючи 3 Тан (Го Вэйцю, 1962: 106). До часу Сун відносяться перші кольорові відбитки на папері, де відбиток робився з однієї дошки, на яку відразу накладалося декілька кольорів. На межі XVIXVII століть з'явилося багато видань, віддрукованих у техніці таобань, (буквально «комплект дощок»). Для отримання кольорової картинки гравіювалося декілька однакових дощок, різнозабарвлені кліше послідовно накладалися на один і той самий аркуш. Метод таобань був основним, усі інші технічні інновації були його модифікацією та інтерпретацією.

Метод таобань використовували вибірково, для друку особливих видань - альбомів різного характеру, географічних праць із багатобарвними картами, наукових праць із коментарями і анота- 
ціями. 3'явилися майстерні, що спеціалізуються на виданні книг із використанням багатоколірного друку. У великому центрі комерційного книговидання, Цзяньянь (або Дзен Нен) такого роду дороговартісна продукція не друкувалася зовсім i метод таобань не знайшов застосування (Chia Lucille, 2002: 251).

Метод таобань упродовж довгих років залишався не основною технікою друкування книг, проте став єдиним у виробництві односторінкових гравюр, названих пізніше няньхуа. Няньхуа змогла максимально використати винахід, призначений не для неї. Невідомо, яка була б доля народної картини, якби видавці книг не відмовилися від багатоколірного друку як основного виду техніки книгодрукування того часу в Китаї.
Висновки. Підсумовуючи, варто зазначити, що визначення народної картини може бути сформульовано так: няньхуа - це різновид багатобарвної ксилографічної гравюри, виготовлений промисловим способом у майстерні друкарні. Художньостилістичні особливості є характерними для кожного осередку виготовлення, яких було декілька. Няньхуа - логічне завершення процесу комерціалізації традиційної культури, що почалася при династії Мін. Метод таобань був основним у технології друкування няньхуа. 3 винаходом багатоколірного друку зовнішній вигляд основної маси китайських книг змінився мало.

Результати нашого дослідження можуть слугувати основою для подальших досліджень художньої історії Китаю та Японії.

\section{СПИСОК ВИКОРИСТАНИХ ДЖЕРЕЛ}

1. Алексеев В. М. Китайская народная картина. Духовная жизнь старого Китая в народных изображениях. Москва: Наука, 1966. 260 с.

2. Муриан И. Ф. Китайский народный лубок. Москва: Искусство,1960. 122 с .

3. Рифтин Б. Л., Шуцунь Ван. Редкие китайские народные картины из советских собраний. Ленинград: Аврора, 1991. $211 \mathrm{c}$.

4. Рудова М. Л. Китайская народная картинка. Санкт-Петербург: Аврора, 2003. 65 с.

5. Флуг К. К. История китайской печатной книги сунской эпохи, X-XIII вв. Москва-Ленинград: Издательство Академии наук СССР, 1959. 400 с.

6. Червова Н. А. Современная китайская гравюра 1931-1958. Москва: Восточная литература, 1960. $171 \mathrm{c.}$

7. 阿英 《中国年画发展史略》，北京，1954年

8. 王树村 《京剧版画》，北京，1959年

9. 王树村 《中国民间年画百图》，北京，1988年

10. 郭味薬 《中国版画史略》，北京，1962年

11. 靳之林 《中国民间艺术》，北京：五洲传播出版社，2004年，139页

12. 周贻白 《南宋杂剧的舞台人物形象》，北京，1960年

13. Chia Lucille. Printing for profit. The commercial publishers of Jianyang, Fujian $\left(11^{\text {th }}-17^{\text {th }}\right.$ centuries $)$. Cambridge (MA); London, 2002

\section{REFERENCES}

1. Alekseev V. M. Kitayskaya narodnaya kartina. Duhovnaya zhizn starogo Kitaya v narodnyih izobrazheniyah. [Chinese folk painting. The spiritual life of old China in folk images]. Moscow, 1966. 260 p. [in Russian].

2. Murian I. F. Kitayskiy narodnyiy lubok. [Chinese folk splint]. Moscow,1960. 122 p. [in Russian].

3. Riftin B. L., Shutsun Van. Redkie kitayskie narodnyie kartinyi iz sovetskih sobraniy. [Rare Chinese folk paintings from Soviet collections]. Leningrad, 1991. 211 p. [in Russian].

4. Rudova M. L. Kitayskaya narodnaya kartinka. [Chinese folk picture]. Sankt-Peterburg, 2003. 65 p. [in Russian].

5. Flug K. K. Istoriya kitayskoy pechatnoy knigi sunskoy epohi, X-XIII vv. [History of the Chinese printed book of the Song era, X-XIII centuries]. Moscow; Leningrad, 1959. 400 p. [in Russian].

6. Chervova N. A. Sovremennaya kitayskaya gravyura 1931-1958. [Contemporary Chinese engraving 1931-1958]. Moscow, 1960. 171 p. [in Russian].

7. 阿英 《中国年画发展史略》，北京，1954年[A Brief History of the Development of Chinese New Year Pictures], Beijing, 1954. [in Chinese ].

8. 王树村 《京剧版画》，北京，1959年[Printmaking of the Peking Opera], Beijing, 1959. [in Chinese ].

9. 王树村 《中国民间年画百图》，北京，1988年 [One Hundred of the Chinese Folk New Year Pictures ], Beijing, 1988. [in Chinese ].

10. 郭味蔡 《中国版画史略》，北京，1962年 [A Brief History of Chinese Printmaking], Beijing, 1962. [in Chinese ].

11. 靳之林 《中国民间艺术》，北京：五洲传播出版社，2004年，139页[Chinese Folk Art], Beijing: Wuzhou Communication Publishing House, 2004, P139. [in Chinese ].

12. 周贻白 《南宋杂剧的舞台人物形象》，北京，1960年 [Images of Stage Characters in Zaju of the Southern Song Dynasty], Beijing, 1960. [in Chinese ].

13. Chia Lucille. Printing for profit. The commercial publishers of Jianyang, Fujian $\left(11^{\text {th }}-17^{\text {th }}\right.$ centuries $)$. Cambridge (MA); London, 2002. [in English]. 